\title{
Residential Development and Hierarchical Governance: Multifamily Housing and Multilevel Analysis
}

\author{
Sang-Chul Park,* Chang Gyu Kwak,** and Sung-Wook Kwon****
}

\begin{abstract}
This study investigates factors that influence multifamily housing zoning from a hierarchical governance perspective. Local zoning is a product of interactive processes among various stakeholders and of local politics. Since local zoning represents community interests in land development and has an exclusionary characteristic, multifamily housing zoning is controversial in some localities. We hypothesize that a hierarchical governance structure influences the supply of local multifamily housing zoning. The result of a hierarchical generalized linear model shows evidence that state smart growth reform and state intervention in local land use are positively associated with the establishment of local multifamily housing zoning. The decisions are also affected by local factors such as the supply of land, density restrictions, cost of new infrastructure, and city budget constraints. This study concludes that state authority and smart growth reform make it possible for local governments to commit to multifamily housing zoning to achieve housing affordability and high-density development.
\end{abstract}

Keywords: multifamily housing zoning, hierarchical governance, smart growth management

* Sang-Chul Park is a postdoctoral research associate in the Florida Department of Environmental Protection and the Hinkley Center. His research interests include hierarchical and local governance, smart growth management, and urban and health policy. E-mail: sp06m@my.fsu.edu.

** Chang Gyu Kwak is a doctoral student in the Askew School of Public Administration and Policy at Florida State University. His research interests include local governance, technology innovation, and energy policy. E-mail: ck10e@my.fsu.edu.

*** Sung-Wook Kwon (corresponding author) is an assistant professor in the Department of Political Science at Texas Tech University. His research interests include intergovernmental collaboration, economic and sustainable development, local service delivery, and local political institutions. E-mail: sung.kwon@ttu.edu.

Manuscript received June 8, 2012; out for review June 26, 2012; review completed August 14, 2012; accepted August 16, 2012.

The Korean Journal of Policy Studies, Vol. 27, No. 2 (2012), pp. 1-22.

(C) 2012 by the GSPA, Seoul National University 
Zoning is regarded as a tool for land use regulation and is defined as a municipality's right to govern land in its jurisdiction. Zoning processes have a political nature, and zoning is understood as the product of interaction among various stakeholders who have different preferences and incentives for land use development. Furthermore, since a zoning decision results in winners and losers who reap its benefits and pay its costs, many studies acknowledge that certain local contextual factors influence local zoning regulation and residential development. These contextual factors include local politics, interest groups, community demographics, and the physical environment.

Multifamily housing zoning has a complex political nature and is a controversial issue for local governments. On the one hand, it creates a positive image for local governments and is associated with social justice and housing affordability for lowand moderate-income families as well as deconcentration of poverty (McClure, 2008). Increasing multifamily housing enables low-income people to live near the workplace and helps local governments achieve efficient use of public services and infrastructure (CPR, 2002). Furthermore, by providing multifamily housing, local governments can create jobs and stimulate local economic development in terms of both immediate and long-term employment and spending in the local economy (Wardrip, Williams, \& Hague, 2011). Thus, many local governments' comprehensive plans include land use policies that are favorable to affordable housing such as inclusionary zoning, a density bonus, and mixed and compact development that are also fundamentally forms of environmental preservation (Pendall, 1999).

On the other hand, multifamily housing zoning is negatively perceived due to potential problems such as high population density, high crime rates, environmental pollution, and traffic congestion, which decrease housing and land values (Fischel, 2001; Haughey, 2003; Knaap et al., 2007; Obrinsky \& Stein, 2007; Park, Feiock, \& Kwon, 2012). Because of this negative perception, multifamily housing zoning faces opposition from citizens, developers, and even local governmental officials. Thus, it is difficult to expect high levels of commitment from local government and the community to multifamily housing zoning.

A hierarchical governance perspective is an influential perspective from which we can analyze local establishment of multifamily housing zoning as it explains both the influence of upper-level governments and the commitment of lower-level governments. According to Fischel (1999) and Park, Feiock, and Kwon (2012), even though zoning for residential development is established by local government with the power to regulate land use development patterns, state and federal institutions credibly affect formation of the local land use planning environment. Moreover, Fischel (1999, p. 407) specifies that "controlling residential zoning explicitly contain the land use planning environment of higher level of government, reflecting state- and region-wide interests." 
This study investigates the influence of both hierarchical governance systems and local factors on multifamily housing zoning. Previous studies that have examined factors influencing land use regulation and residential development have constructed theoretical and analytical frameworks focusing on a single level of local government without consideration of dynamics that may function between state and local levels. According to Bollens (1992), instead of focusing on local growth management policies, the consolidated roles and rules of state and local governments should be investigated through diverse intergovernmental frameworks. In particular, he points out that a reason for transferring land use authority from local to state government is to solve the unwillingness and inability of local government to handle growth-related problems (such as environmental protection, affordable and multifamily housing, and public facilities). That is, while existing studies have implicitly accepted that multifamily housing is a local governance issue, this field will be expanded and improved if we find evidence of multilevel governance. Thus, this study is expected to contribute to the research by examining the effects of state-level factors on the establishment of local multifamily housing zoning.

\section{HIERARCHICAL GOVERNANCE STRUCTURE}

A key aspect of governance is the collaboration between diverse actors that may include different levels of government and various stakeholders in public, private, and nonprofit organizations. Based on the collective action perspective, Emerson, Nabatchi, and Balogh (2011, p. 2) define governance as "mutually-shared understanding which determines norms and rules designed to regulate individuals and group behaviors." More specifically, it involves coordination and regulation processes that secure policy commitment in pursuing collaborative actions on certain policies (Bryson, Crosby, \& Stone, 2006).

The perspective of hierarchical governance is elaborated by transaction cost theory. This theory, originated in Coase's The Nature of the Firm (1937), states that hierarchy is regarded as an alternative structure to the market (Williamson, 1975). According to transaction cost theory, the hierarchical structure can reduce the cost that is consistent with the uncertainty of mutual agreement and commitment in the managerial decisionmaking process.

Geyskens, Steenkamp, and Kumar (2006, p. 519) argue that asset specificity, volume uncertainty, and behavioral uncertainty are positively correlated with the choice of hierarchical governance over marketized structure. This may imply that state action is necessary to reduce local complexity from various conflicts in local policy-making 
processes, which consequently minimizes transaction costs. That is, from the perspective of intergovernmental relations, state regulatory authority and intervention are able to reduce the costs of local complexity and conflicts by achieving efficient cooperation among local governments. Thus, hierarchical rules can resolve commitment problems through the formal rule structure and shape the agreement between state and local governments.

The concept of holon (Ostrom, 1990) can help to explain hierarchical governance. It describes rules as being nested in higher levels of institutions or decisions. This means that institutions and policy actions cannot be isolated to a single level of government; rather, multilevel governmental relationships should be considered when we study decision-making related to a certain policy. This perspective has been frequently cited in recent research. For example, Tavares et al. (2008) use multilevel analysis to investigate nested structure in order to explain policy outcomes in which they identify the factors influencing decision delay in land use decision-making at the municipal level. Likewise, Park, Feiock, and Kwon (2012) define state governments as the upper-level participants in local residential development decisions and reveal that the state government authority reduces conflicts in local decision-making processes.

McCabe and Feiock (2001) focus on the hierarchical governance structure in the relations between state and local governments. They argue that states' constitutional rules and institutions determine local governments' policy choices and emphasize local government responsibility for state institutional goals. When externality problems are caused across jurisdictions or are regional in character, the authority delegated to local governments will be less efficient when promoting the allocation and redistribution of policy consequences. Likewise, regarding intergovernmental relations, Turner (1990) argues that there is a complicated pattern when the policy authority is divided into states and local governments. Specifically, he argues that the partial delegation of authority from state to local governments causes more complex decision-making rules and less discretion due to unclear policy authority. Thus, the policy authority must be clearly defined by a strong hierarchical structure to achieve mutual adjustment.

\section{SMART GROWTH MANAGEMENT AND MULTIFAMILY HOUSING}

Growth management policy is regarded as a regulatory policy through which state government influences land use policy choices and outcomes of local governments (Park, Park, \& Lee, 2010; Feiock, 1994). Therefore, it is an important mechanism of hierarchical governance in the area of multifamily housing zoning. This regulatory policy has been developed with the objective of integrating development interests with 
environmental protection. Carruthers (2002, p. 1962) portrays intergovernmental relationships in growth management policies as follows: "(1) vertical consistency is consistent with state-defined policy objectives, (2) horizontal consistency is related with local plans, and (3) internal consistency is related to concerns about local plans interacting with development regulation (e.g., zoning ordinance)." That is, growth management involves both vertical and horizontal intergovernmental relations, aiming to integrate state and local government regulations and promote policy consistency within and between governments while reducing community-wide negative externalities from excessive urban and suburban development (Park, Park, \& Lee, 2010).

Growth-management policy can be seen as developing in two phases. During the 1970s and 1980s, it aimed to control urban growth and preserve the natural environment (Weitz, 1999). During this period, states regulated urban service boundaries and region-wide land use development. This early growth management era was more likely to prevent the urban sprawl that causes expansion of urban boundaries, environmental pollution, and social segregation. Under this strong growth control, urban development is characterized by a "doughnut" pattern in which businesses and wealthy residents migrate to suburban areas and core city areas become hollowed out and populated primarily by poor residents.

As a result, second-order sprawl takes place in suburbs that are not within the previous urban service boundaries. For example, since many people must commute from suburban to urban areas, commute time, air pollution, and traffic congestion become social problems. Furthermore, residential development in suburbs allows developers to use large lot sizes for single-family houses, which increases housing values and results in less housing affordability.

Thus, states redirect the regulatory means of growth management to balance housing affordability and residential development interests under the presumption of environmental preservation. This second phase of growth management is regarded as smart growth management, which emphasizes the role of local governments committed to pursuing comprehensive land-use plans that result in reduced suburban (second-order) sprawl and development of inner-city areas. Smart growth management encourages local governments to promote density development that is positively associated with housing affordability through various policy instruments such as inclusionary zoning, regional fair-share housing, lower cost of new infrastructure, and minimizing regulation (Nelson et al., 2002, p. 7).

However, without a state-level growth management policy, the economic function and exclusionary nature of zoning can be barriers to high-density development and multifamily housing production. Since zoning determines local land development patterns and strongly influences neighborhood property values, multifamily housing 
zoning can be perceived negatively. Also, intergovernmental competition could explain why local governments may not be willing to provide multifamily housing. Influenced by competition from other local governments, city governments may concentrate on economic and land development policies so as to secure governmental resources and fiscal stability. Focusing on economic development, cities are less likely to promote multifamily housing, which is regarded as a redistributive policy (Peterson, 1981; Fischel, 2001). Thus, local governments are more likely to promote lower-density development (single-family housing developments or commercial developments) rather than high-density development (multifamily housing developments and affordable housing). In this situation, state intervention based on smart growth management can help local governments improve their accountability by establishing multifamily housing zoning (Bollens, 1992).

While smart growth management is generally expected to improve high-density development and housing affordability as mentioned above, its impact on multifamily housing zoning should receive more attention. In spite of its positive image, multifamily housing has a strongly negative image for residents as well, which makes multifamily housing zoning difficult to provide in practice. Thus, the positive relationship between state smart growth management policy and local multifamily housing zoning may not be easily observed. Whether smart growth management can achieve its goals in the complex and controversial issue of multifamily housing has not been answered in previous studies and should be addressed through empirical tests.

\section{LOCAL CONTEXTS AND MULTIFAMILY HOUSING}

Multifamily housing zoning can be an outcome of the interaction between political institutions, community, and physical characteristics of local governments. While upperlevel institutions affect the policy choices and outcomes of lower-level institutions, collective choices go through interactive processes between local politics and community preferences under the conditions of the physical environment (Ostrom, 2005).

Travares et al. (2008) and Park, Feiock, and Kwon (2012) investigate the effects of political institutions on the approval time for land use development. These studies provide three insights: First, political institutions mediate diverse interests and conflicts among local stakeholders, and those mediating effects reduce the length of approval or review time for multifamily housing development. Second, the longer approval time is needed, the more stringent land use development and regulation are likely to be. Third, the rezoning for multifamily housing development is more controversial, and the role of professional groups (such as environmental review groups, planning commissioner, 
and local zoning board) is important in reducing local conflicts with regard to decisions on multifamily housing development.

While political institutions, particularly city councils, can play a significant role in decisions on local land use issues, residents' priorities are also an influential predictor of the decision-making processes. Persson and Tabellini (2000, p. 20) argue that individuals (residents) get involved in policy decision-making processes through "voting, lobbying or other behaviors influencing local political institutions." Lubell, Feiock, and Ramirez (2005) and Yoo and Park (2010) emphasize the importance of community demographics concentrated on narrow preferences, when local governments enact land use institutions and regulations governing residential development. That is, citizen consensus or agreement about multifamily housing zoning is more likely to influence the site and size of a zone. Thus, opposition from city council and citizens to multifamily housing is assumed to be negatively related to the extent of multifamily housing zoning.

Impact fees may have significance for multifamily housing. An impact fee is defined as a "one-time fee imposed on new development to fund public facility improvements required by new development and ease fiscal burdens on localities" (Burge \& Ihlanfeldt, 2006; Lawhon, 2007). Local governments can share the costs for land development by imposing impact fees on developers. According to previous studies, real estate developers that prioritize large lot size and low-density development in single-family housing construction and commercial development can maximize profits from increased property values (Mathur, Waddell, \& Blanco, 2004; Evans-Cowley, Forgey, \& Rutherford, 2005). Thus, the use of impact fees may limit multifamily housing zoning, since multifamily housing development posits high density and small lot size development consistent with low property values.

Land development and zoning processes are strongly related to existing land use patterns and physical conditions. Even though local governments are willing to develop residential areas, their current physical condition may make it difficult to generate new residential development. Unless local governments possess land that is available to be developed, zoning for multifamily housing development cannot be easily achieved. Likewise, density is regarded as an important factor in land use and zoning permission. Kang and Feiock (2006) argue that density and land availability are critical factors that can be used to test the effect of growth context on land use regulation. This is consistent with Miller's (1986) finding that housing density regulations are negatively associated with promotion of housing affordability and multifamily housing construction. Overall, less land supply and high housing density restrictions will result in less multifamily housing zoning.

In addition to physical conditions, budget constraints and high costs for new infra- 
structure are considered a burden for local governments in zoning selection. Inconsistency between fiscal constraints and zoning policies has an impact on new infrastructure development. The burden of cost transfers to developers, taxpayers, and landowners results in difficulty utilizing residential development (Weitz, 1999). That is, multifamily housing zoning needs extensive new infrastructure (such as schools, transportation, water supply and sewers, and public facilities) supported by financial stability (Nelson et al., 2002). Consequently, the fiscal burden and high costs of new infrastructure can influence land use zoning and multifamily housing development in a negative way (Chapman, 1988).

\section{DATA AND METHODS}

Data for an empirical analysis were obtained from two sources. City-level data were drawn from a survey on residential land use regulation conducted by the University

Table 1. Measurement of Variables

\begin{tabular}{|c|c|}
\hline Variable & Measurement \\
\hline \multicolumn{2}{|l|}{ State level } \\
\hline Growth management & Dummy variable $(1=$ enacted, $0=$ not enacted $)$ \\
\hline Smart growth management & $\begin{array}{l}\text { 4-point Likert scale ( } 0=\text { no reform movement, } 3=\text { substantial } \\
\text { movement) }\end{array}$ \\
\hline $\begin{array}{l}\text { Strong state authority* smart growth } \\
\text { management }\end{array}$ & $\begin{array}{l}\text { Strong state authority is a dummy variable ( } 1=\text { state has } \\
\text { authority over local land use, } 0=\text { otherwise) }\end{array}$ \\
\hline $\begin{array}{l}\text { Authority shared between state and local } \\
\text { government* smart growth management }\end{array}$ & $\begin{array}{l}\text { Shared state authority is a dummy variable ( } 1=\text { state shares } \\
\text { local land use authority with local government, } 0=\text { otherwise) }\end{array}$ \\
\hline \multicolumn{2}{|l|}{ Local level } \\
\hline $\begin{array}{l}\text { Dependent variable: } \\
\text { Supply of multifamily housing zoning in } \\
\text { excess of citizen demand }\end{array}$ & $\begin{array}{l}\text { Dummy variable }(1=\text { multifamily housing zoning is more than } \\
\text { demand, } 0=\text { multifamily housing zoning is less than or equal } \\
\text { to demand) }\end{array}$ \\
\hline $\begin{array}{l}\text { Independent variables:* } \\
\text { - City council opposition } \\
\text { - Impact fee } \\
\text { - Citizen opposition } \\
\text { - Supply of land } \\
\text { - Cost of new infrastructure } \\
\text { - City budget constraints } \\
\text { - Density restriction }\end{array}$ & $\begin{array}{l}\text { 5-point Likert scale ( } 1=\text { not important at all; } 5=\text { very } \\
\text { important) }\end{array}$ \\
\hline
\end{tabular}

* Higher score means city has greater concern. 
of Pennsylvania's Wharton School in 2005. State-level growth management and smart growth reform data were retrieved from the website of the American Planning Association. The Wharton survey was sent to 6,896 municipalities nationwide that were on the mailing list of the International City/County Management Association. The respondents were chief administrative officers or planning directors in those municipalities, and the response rate was 38 percent (Gyourko, Saiz, \& Summers, 2007). The appendix shows the Wharton School survey questions that measure the dependent variable and seven city-level independent variables used in our study.

The dependent and independent variables were collected for the years 2004 and 2005; measures and descriptive statistics for these variables are presented in tables 1 and 2. The unit of analysis in our model is the municipality, while the state factors are combined into one model. The dependent variable in our model is a dummy variable that indicates whether or not a municipality has established multifamily housing zoning in excess of citizens' demand for multifamily housing development; this was true for 17 percent of municipalities.

Table 2. Descriptive Statistics

\begin{tabular}{|c|c|c|c|c|c|}
\hline Variable & Obs. & Mean & S.D. & Min & Max \\
\hline \multicolumn{6}{|l|}{ State level } \\
\hline Growth management & 49 & 0.24 & 0.43 & 0 & 1 \\
\hline Smart growth management & 49 & 1.29 & 1.06 & 0 & 3 \\
\hline Strong state authority* smart growth management & 49 & 0.31 & 0.92 & 0 & 3 \\
\hline $\begin{array}{l}\text { Authority shared between state and local government* } \\
\text { smart growth management }\end{array}$ & 49 & 0.78 & 0.96 & 0 & 3 \\
\hline \multicolumn{6}{|l|}{ Local level } \\
\hline \multicolumn{6}{|l|}{ Dependent variable: } \\
\hline Supply of multifamily housing zoning compared to demand & 2,410 & 0.17 & 0.38 & 0 & 1 \\
\hline \multicolumn{6}{|l|}{ Independent variables: } \\
\hline City council opposition to growth & 2,410 & 2.37 & 1.42 & 1 & 5 \\
\hline Impact fee & 2,410 & 2.14 & 1.24 & 1 & 5 \\
\hline Citizen opposition to growth & 2,410 & 2.82 & 1.36 & 1 & 5 \\
\hline Supply of land & 2,410 & 3.89 & 1.38 & 1 & 5 \\
\hline Cost of new infrastructure & 2,410 & 3.37 & 1.30 & 1 & 5 \\
\hline City budget constraints & 2,410 & 2.31 & 1.39 & 1 & 5 \\
\hline Density restriction & 2,410 & 3.28 & 1.40 & 1 & 5 \\
\hline
\end{tabular}


The independent variables were collected from two different levels of government. First, state-level factors were constructed as higher-level predictors in our model. ${ }^{1}$ These generally fit into three categories: conventional growth management, smart growth reform, and intergovernmental relations combined with state land use authority and smart growth management. Table 3 summarizes state laws that promote conventional growth management.

Table 3. State Laws Related to Conventional Growth Management

\begin{tabular}{l|l|l}
\hline \multicolumn{1}{c|}{ State } & Year & \multicolumn{1}{c}{ Name of legislation } \\
\hline Hawaii & 1961 & Hawaii State Land Use Law \\
\hline California & 1965 & California Land Conservation Law \\
\hline Vermont & 1970 & Growth Management Act \\
\hline Oregon & 1973 & Land Conservation and Development Act \\
\hline Florida & 1985 & Omnibus Growth M anagement Act \\
\hline New Jersey & 1986 & State Planning Act \\
\hline Maine & 1988 & Comprehensive Planning and Land Use Regulation Act \\
\hline Rhode Island & 1988 & Comprehensive Planning and Land Use Regulation Act \\
\hline Georgia & 1989 & Georgia Planning Act \\
\hline Washington & 1990 & Growth Management Act \\
\hline Maryland & 1992 & Economic Growth, Resource Protection and Planning Act \\
\hline Arizona & 1998 & Growth Smarter Act \\
\hline Tennessee & 1998 & Growth Policy Act \\
\hline
\end{tabular}

Sources: Park et al. (2010, p. 49); Anthony (2004); Howell-M oroney (2008).

The extent of smart growth reform (table 4) is a summated index by the legislative activities and specified smart growth planning and policy initiatives related to issues such as land use, open space conservation, housing affordability, green economic development, transportation, mixed and high-density development, and coastal preservation. For instance, according to a recent report on planning for smart growth (APA, 2012, pp. 14-20), the extent of smart growth reform is based on indicators such as polls, legislation, executive orders, budget proposals, and ballot initiatives.

1. The state of Hawaii was excluded because only one city in the state was observed in the survey. A single observation within a group is not reliable when investigating the effect of group variability on individual-level outcomes. 
Table 4. State-Level Smart Growth Reform, 2000-2001

\begin{tabular}{|c|c|}
\hline State & Reform \\
\hline \multicolumn{2}{|c|}{ Governor's Executive Order } \\
\hline Arizona & No. 2001-02, creating the Growing Smarter Oversight Council \\
\hline California & $\begin{array}{l}\text { D-46-01, directing state Department of General Services to reuse state buildings in } \\
\text { central cities }\end{array}$ \\
\hline Delaware & No. 14, directing state agencies and departments to implement steps curbing sprawl \\
\hline Indiana & No. 01-03, establishing the Indiana Land Use Forum \\
\hline Maryland & $\begin{array}{l}\text { No. 01.01.2001.01, creating the Commission on Environmental Justice and } \\
\text { Sustainable Communities }\end{array}$ \\
\hline Massachusetts & No. 418, creating a two-year Community Development Plan Program \\
\hline Missouri & $\begin{array}{l}\text { No. 01-16, establishing the M issouri Commission on Intergovernmental Cooperation } \\
\text { No. 01-19, directing the executive branch to help achieve measurable improvements } \\
\text { in state's quality of life }\end{array}$ \\
\hline Oregon & $\begin{array}{l}\text { No. } 00-07 \text {, to address sustainability issues and establish the Governor's Work Group } \\
\text { on Sustainability }\end{array}$ \\
\hline South Carolina & $\begin{array}{l}\text { No. 2001-09, creating an affordable housing task force } \\
\text { No. 2001-11, establishing a swine facilities moratorium }\end{array}$ \\
\hline Tennessee & Executive order to establish Strategically Targeted Areas of Redevelopment \\
\hline Vermont & $\begin{array}{l}\text { No. 01-00, creating a Development Cabinet } \\
\text { No. 01-07, fostering conservation of land near interstate highway interchanges and } \\
\text { discouraging strip-type development along these areas }\end{array}$ \\
\hline \multicolumn{2}{|c|}{ Commissions and task forces } \\
\hline Alabama & Alabama Commission on Environmental Initiatives: report, January 2001 \\
\hline Colorado & $\begin{array}{l}\text { Governor's Commission on Saving Open Spaces, Farms and Ranches: } 11 \text { proposals, } \\
\text { December } 2000\end{array}$ \\
\hline Florida & Growth M anagement Study Commission: report, February 2001 \\
\hline Illinois & $\begin{array}{l}\text { Balanced Growth Cabinet } \\
\text { Illinois Growth Task Force: series of reports, } 2000\end{array}$ \\
\hline Kentucky & Bipartisan Task Force on Smart Growth: report, November 2001 \\
\hline New Hampshire & $\begin{array}{l}\text { Three study commissions to address affordable housing, shoreland protection, and } \\
\text { rail transit: reports, November } 2001 \text { and January } 2002\end{array}$ \\
\hline New York & Quality Communities Interagency Task Force: report, January 2001 \\
\hline North Carolina & $\begin{array}{l}\text { Commission to Address Smart Growth Management and Development Issues: report, } \\
\text { November } 2001\end{array}$ \\
\hline North Dakota & $\begin{array}{l}\text { Study to examine use of conservation easements to protect farmland and recreational } \\
\text { lands }\end{array}$ \\
\hline Rhode Island & $\begin{array}{l}\text { Growth Planning Council: first annual report, August } 2001 \\
\text { Commission to study how state government can encourage sustainability: report, } \\
\text { January } 2002\end{array}$ \\
\hline Vermont & $\begin{array}{l}\text { Land-use permitting process study commission, affordable housing study commission, } \\
\text { and downtown redevelopment task force }\end{array}$ \\
\hline Virginia & Commission on Growth and Economic Development \\
\hline
\end{tabular}

Source: APA (2002); http://www.miami21.org/PDFs/Planning\% 20for\% 20Smart\% 20Growth.pdf 
Figures 1 and 2 show the strength of smart growth reform and the correlation between the extent of smart growth reform and conventional growth management for all states except Hawaii. They show that, among the 49 states, 9 have substantial movement toward smart growth in statewide policies; 9 have moderate movement; 18 have less moderate movement; and 13 have no substantial movement toward smart growth. In states that have enacted conventional growth management laws, the extent of smart growth reform is higher than in those that did not.

For the first and second part of our analysis, two different state-level variables are used to measure the effects of conventional and smart growth management on local multifamily housing zoning. We test whether conventional growth management or smart growth management initiatives affect the extent of multifamily housing zoning at the local level. The conventional growth management variable is a dummy variable: if a state enacts growth management, it is coded 1, otherwise 0 . The smart growth management variable is measured by categorical data ranging from 0 to 3 , where 0 indicates no smart growth reform and 3 indicates substantial reform. While both variables show the level of state growth management efforts, they need to be examined in separate models as they reflect different contexts in the growth management issue, as explained above, and may have a different influence on the extent of local multifamily housing zoning.

For the third section of the analysis, we construct interaction terms in order to test

Figure 1. State Smart Growth Reform

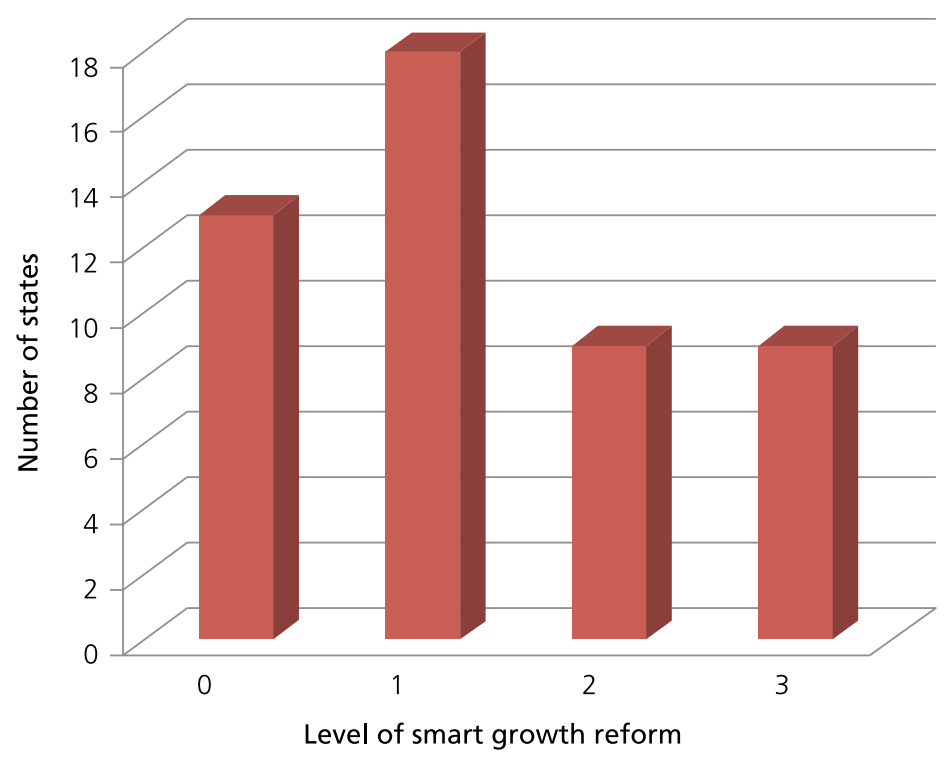

The Korean Journal of Policy Studies 
Figure 2. Relationship between Smart Growth Reform and Conventional Growth Management

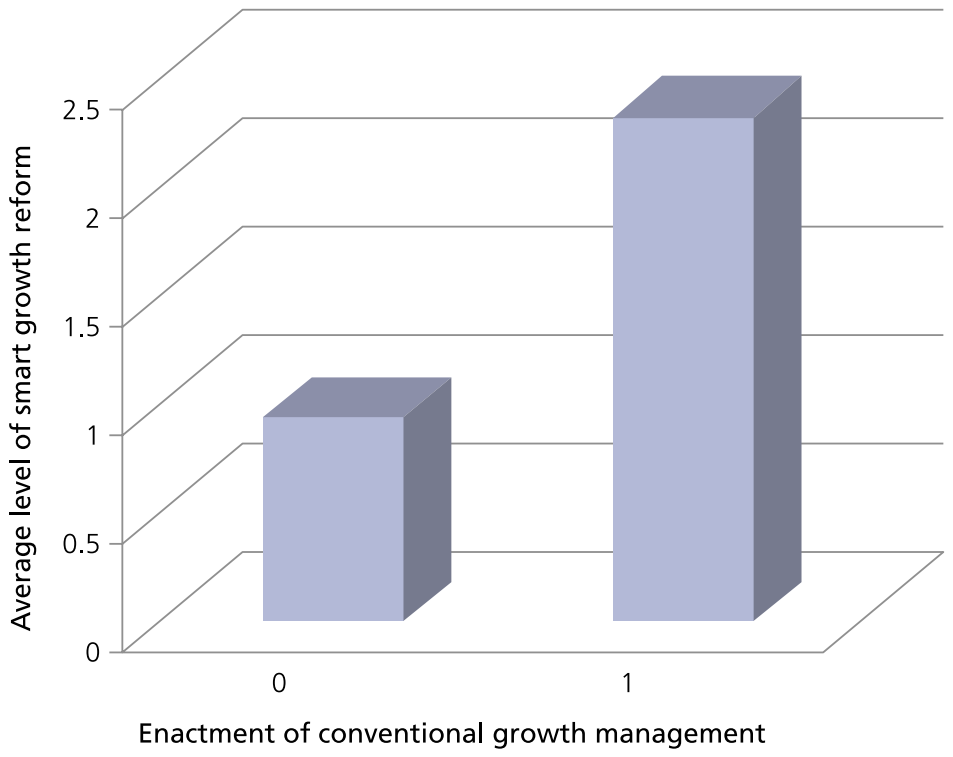

the effects of intergovernmental relations. Two interaction terms are created by multiplying by two variables: the extent of state land use authority and the extent of smart growth management reform. State land use authority is measured by two dummy variables: (1) whether a state has authority over local land use and (2) whether a state shares its authority with local government. These two variables are then multiplied by the level of the state smart growth management variable explained above. Those interaction term variables are created and tested, focusing on state smart growth management effort as it is more directly related to the multifamily housing issue than conventional growth management is.

Local-level predictors include city council opposition to multifamily housing construction, impact fee requirements, citizen opposition, land supply, cost of new infrastructure, city budget constraints, and density restrictions. The data for these variables were obtained from the Wharton School's survey questions that asked city officials to evaluate the importance of each in regulating multifamily housing development in their communities. The regulating rate for each variable ranges from 1 (not important at all) to 5 (very important). Thus, if a variable has a higher score, it means that the city has a stronger concern about the variable's effect on multifamily housing development.

To analyze the data, we run a multilevel analysis using HLM software. Before a multilevel model is analyzed, we conduct a one-way ANOVA analysis in order to find 
variation among states on the distribution of multifamily housing zoning. The result reported in table 5 shows that the odds of average supplied multifamily housing zoning are about 0.21 across states, which means 17.6 percent of municipalities provide multifamily housing zoning that is greater than current demand. ${ }^{2}$ Governmental hierarchy as an explanation for the extent of multifamily housing zoning is verified by the statistically significant variance components $(\mathrm{p}<0.000)$.

Table 5. One-Way ANOVA Model Analysis

\begin{tabular}{c|c|c|c|c|c}
\hline \multicolumn{1}{c|}{ Fixed effect } & & Coefficient & Se & T-ratio & p-value \\
\hline Average supply of multifamily housing zoning, $\gamma_{00}$ & & -1.545 & 0.088 & -17.519 & 0.000 \\
\hline & & Odds ratio & C.I. & & \\
\hline Random effect & & 0.213 & $(0.178,0.255)$ & & \\
\hline State mean & S.D. & $\begin{array}{c}\text { Variance } \\
\text { component }\end{array}$ & df & $\chi^{2}$ & $p$-value \\
\hline & 0.435 & 0.189 & 48 & 103.536 & 0.000 \\
\hline
\end{tabular}

To test the hierarchical governance structure for 2,410 cities in the 49 states included in our analysis, we construct five models: an unconditional model, tested by including only local-level predictors, and four simple random-intercept models (SRIM), which are conditional with four different state factors based on the unconditional model. The following equations specify our multilevel models:

\section{Unconditional model}

Prob (Supply of Multifamily Housing Zoning $_{\mathrm{ij}}=1 \mid \beta_{\mathrm{j}}$ ) $=\varphi_{\mathrm{ij}}$ $\log \left[\varphi_{\mathrm{ij}} /\left(1-\varphi_{\mathrm{ij}}\right)\right]=\eta_{\mathrm{ij}}$

$\eta_{\mathrm{ij}}=\gamma_{00}+\gamma_{10}\left(\right.$ Council Opposition $\left._{\mathrm{ij}}\right)+\gamma_{20}\left(\right.$ Impact Fee $\left._{\mathrm{ij}}\right)+\gamma_{30}\left(\right.$ Citizen Opposition $\left._{\mathrm{ij}}\right)$

$+\gamma_{40}\left(\right.$ Supply of Land $\left._{\mathrm{ij}}\right)+\gamma_{50}\left(\right.$ Infrastructure Cost $\left._{\mathrm{ij}}\right)+\gamma_{60}\left(\right.$ City Budget $\left._{\mathrm{ij}}\right)$

$+\gamma_{70}\left(\right.$ Density Restriction $\left.{ }_{\mathrm{ij}}\right)+\mathrm{u}_{00}$

\section{Simple random intercept model}

Prob (Supply of Multifamily Housing Zoning $\left._{\mathrm{ij}}=1 \mid \beta_{\mathrm{j}}\right)=\varphi_{\mathrm{ij}}$ $\log \left[\varphi_{\mathrm{ij}} /\left(1-\varphi_{\mathrm{ij}}\right)\right]=\eta_{\mathrm{ij}}$

2. $\gamma_{00}$ is the mean of the $\log (\mathrm{p} / 1-\mathrm{p})$. In Table $5, \gamma_{00}$ is -1.545 . Based on the equation $\pi /(1-\pi)=$ $\mathrm{k}=0.213, \pi$ is equal to 17.55 . Thus, it is probable that about 17.6 percent of municipalities across states will supply multifamily housing zoning that exceeds citizen demand. 


$$
\begin{aligned}
& \eta_{\mathrm{ij}}=\gamma_{00}+\gamma_{01}(\text { State Growth Management Factors })+\gamma_{10}\left(\text { Council Opposition }_{\mathrm{ij}}\right) \\
& +\gamma_{20}\left(\text { Impact Fee }_{\mathrm{ij}}\right)+\gamma_{30}\left(\text { Citizen Opposition }_{\mathrm{ij}}\right)+\gamma_{40}\left(\text { Supply of Land }_{\mathrm{ij}}\right) \\
& +\gamma_{50}\left(\text { Infrastructure Cost }_{\mathrm{ij}}\right)+\gamma_{60}\left(\text { City Budget }_{\mathrm{ij}}\right)+\gamma_{70}\left(\text { Density Restriction }_{\mathrm{ij}}\right)+\mathrm{u}_{00}
\end{aligned}
$$

where $\eta_{\mathrm{ij}}$ is the predicted value of the municipalities' characteristics for municipality $i$ in state $j, \gamma_{10}$ through $\gamma_{70}$ are the coefficients that represent the effects of municipalitylevel variables, $\gamma_{01}$ is the coefficient that represents the effect of the state-level variable, and $\mathrm{u}_{00}$ is a random error in the state-level equation.

\section{EMPIRICAL FINDINGS}

Table 6 shows the results of our hierarchical generalized linear model analysis and significant factors. The results of the unconditional model show the effects of only local factors, and the SRIM models compare the effects of state growth management factors on the extent of multifamily housing zoning. While conventional growth management does not show any significant influence on multifamily housing zoning (Model I), smart growth reform $(\mathrm{p}<0.05)$ positively influences the probability that local governments will establish multifamily housing zoning that exceeds demand (Model II). Also, the interaction effect $(\mathrm{p}<0.05)$ between strong state authority over local land use and smart growth reform increases the probability that local governments will establish multifamily housing zoning that exceeds demand (Model III). However, the interaction effect between shared authority over local land use and smart growth reform is not statistically significant (Model IV). In sum, we find that local governments are likely to establish multifamily housing zoning that exceeds citizen demands when state governments institute substantial smart growth management reforms or possess strong authority over local land use while instituting smart growth management reforms.

The results also show that several local factors influence the establishment of local multifamily housing zoning. Importantly, factors related to physical characteristics show strong significance in our models. In both the unconditional model and SRIM, supply of land $(\mathrm{p}<0.001)$ and density restrictions $(\mathrm{p}<0.005)$ are negatively associated with the establishment of multifamily housing zoning. This result implies that municipalities that suffer from insufficient supply of land and have a strong density restriction are less willing to increase multifamily housing zoning.

However, inconsistent with our hypothetical expectations, when costs of building new infrastructure $(\mathrm{p}<0.05)$ increase and budget constraints are high $(\mathrm{p}<0.05)$, municipalities establish more multifamily housing zoning. While we assumed that local governments' 
Table 6. Results of Analysis of Multifamily Housing Zoning

\begin{tabular}{|c|c|c|c|c|c|}
\hline \multirow{2}{*}{ Fixed effect } & \multirow{2}{*}{$\begin{array}{c}\text { Unconditional } \\
\text { (odds ratio) }\end{array}$} & \multicolumn{4}{|c|}{ SRIM (odds ratio) } \\
\hline & & Model I & Model II & Model III & Model IV \\
\hline Intercept $\gamma_{00}$ & 0.650 & $0.608 * *$ & $0.529 * *$ & $0.613^{*}$ & $0.624 *$ \\
\hline \multicolumn{6}{|l|}{ State growth management factor } \\
\hline Growth management, $\gamma_{01}$ & - & 1.329 & - & - & - \\
\hline Smart growth management, $\gamma_{01}$ & - & - & $1.165^{* *}$ & - & - \\
\hline State authority and smart growth, $\gamma_{01}$ & - & - & - & $1.193^{* *}$ & - \\
\hline Shared authority and smart growth, $\gamma_{01}$ & - & - & - & - & 1.048 \\
\hline \multicolumn{6}{|l|}{ Local-level factors } \\
\hline City council opposition, $\gamma_{10}$ & 0.937 & 0.936 & 0.935 & 0.937 & 0.937 \\
\hline Impact fee, $\gamma_{20}$ & 0.978 & 0.971 & 0.969 & 0.976 & 0.975 \\
\hline Citizen opposition, $\gamma_{30}$ & 0.981 & 0.980 & 0.980 & 0.980 & 0.980 \\
\hline Supply of land, $\gamma_{40}$ & $0.697 * * *$ & $0.694 * * *$ & $0.692 * * *$ & $0.696 * * *$ & $0.697 * * *$ \\
\hline Cost of new infrastructure, $\gamma_{50}$ & $1.114^{* *}$ & $1.120^{* *}$ & $1.124^{* *}$ & $1.116^{* *}$ & $1.116^{* *}$ \\
\hline City budget constraints, $\gamma_{60}$ & $1.113^{* *}$ & $1.118^{* *}$ & $1.122 * *$ & $1.119 * *$ & $1.115^{* *}$ \\
\hline Density restriction, $\gamma_{70}$ & 0.940 & 0.939 & $0.936 * *$ & $0.940 * *$ & 0.939 \\
\hline Random effect & $\begin{array}{c}\text { Variance } \\
\text { component }\end{array}$ & $\begin{array}{c}\text { Variance } \\
\text { component }\end{array}$ & $\begin{array}{c}\text { Variance } \\
\text { component }\end{array}$ & $\begin{array}{c}\text { Variance } \\
\text { component }\end{array}$ & $\begin{array}{c}\text { Variance } \\
\text { component }\end{array}$ \\
\hline State mean, $\mathrm{u}_{00}$ & $0.089 * *$ & $0.081^{* *}$ & $0.064 * *$ & $0.070 * *$ & $0.093^{* *}$ \\
\hline
\end{tabular}

Note: $* p<0.1 ; * * p<0.05 ; * * * p<0.01$

incentive to provide multifamily housing would be limited by these burdens, the results show that local governments tend to pursue small-lot-size development in urban areas in response to the problems in land use. When their general development activities are reduced due to the burdens, local governments may focus on multifamily housing construction by utilizing existing infrastructure in order to save the costs of purchasing large landed estates and constructing new infrastructure. Other local factors, such as opposition from city council and citizens and the imposition of animpact fee, do not affect the local establishment of multifamily housing zoning. In sum, our results show that existing physical characteristics are the main determinants of the provision of multifamily housing zoning at the local level. 


\section{IMPLICATIONS AND DISCUSSION}

This study focuses on multifamily housing zoning to test hierarchical governance between state and local governments. Since zoning is a product of local governments' efforts to promote their interests regarding land development, and has exclusion as a characteristic, multifamily housing zoning is controversial in some localities. By investigating hierarchical governance, this study identifies that strong state intervention and smart growth reform influence local land use decisions on multifamily housing and effectively encourage local governments to establish multifamily housing zoning.

State growth management accounts for the role of high-level government, which affects local governments' establishment of multifamily housing zoning. Our analysis shows that the smart growth reform movement is positively associated with multifamily housing zoning, while conventional growth management is not. Since conventional growth management is more likely to concentrate on controlling urban growth and alleviating urban density, it may not encourage multifamily housing zoning in urban areas. However, smart growth reform essentially aims to develop urban areas through mixed and compact development, promoting high-density development while enhancing housing affordability. And the analysis shows that smart growth management helps local governments establish multifamily housing zoning even though this zoning is controversial and not in an agreement among residents because of its negative aspects.

Also, when smart growth reform is accompanied by a state's strong authority over local land use, more multifamily housing zoning is established than is demanded by citizens. Since multifamily housing development is perceived negatively by local governments and citizens in general, many local governments have avoided it and have introduced other types of development through which they can increase local revenues and attract private investment related to economic, commercial, and singlefamily housing development.

Thus, state intervention in local land use can be more effective in establishing multifamily housing zoning. State intervention attempts to utilize local land through statewide land use planning objectives in order to prevent locally concentrated interests in residential development. Further, intervention under smart growth reform can help local governments pursue inner-city development while resolving housing affordability and environmental issues.

Among local contextual factors, physical environment is influential in determining multifamily housing zoning. When local governments have a limited land supply and must increase density for residential development, more multifamily housing zoning tends to be established. Since multifamily housing zoning is based on high-density development, the localities that already have high density may switch their land use 
development patterns toward low-density development. Likewise, local governments facing a lack of land to utilize for multifamily housing construction, not surprisingly, cannot produce it. That is, the physical environment can be a key dimension in the pursuit of multifamily housing zoning.

The construction market and governmental fiscal status can be reasons to promote multifamily housing zoning. One of the reasons to pursue high-density development is to make better use of existing infrastructure. Focusing on density and compact development in urban areas, local governments can take advantage of well-organized infrastructure that already exists in urban areas and utilize it for multifamily housing construction. Similarly, the utilization of existing infrastructure as a means of cost savings can be a solution to budget constraints in multifamily housing development. In general, when local governments initiate residential development, the cost of new infrastructure depends on the types and sizes of housing that local governments develop. When local governments face budget constraints, they may find a way to develop multifamily housing using existing infrastructure.

While the physical environment and infrastructure are significant predictors determining provision of multifamily housing zoning, city council opposition, citizen opposition, and use of impact fees do not affect it. This may imply that, even though local politicians and citizens are crucial actors in residential development decision processes, multifamily housing zoning is more likely to be constrained by physical conditions. Even when local governments have a strong willingness to establish multifamily housing zoning, it is difficult to carry out in practice when physical and financial conditions are not favorable. Likewise, we expected the use of impact fees to be negatively associated with the establishment of multifamily housing zoning, but such fees actually had little effect.

In sum, this study has significance in terms of empirical testing of a hierarchical federal system. Using multifamily housing zoning, it examines the effects of state government intervention and the role of smart growth reform. While the effect of state smart growth reform on local government policy choices has been discussed, few studies have empirically tested the relationship between higher- and lower-level governments. This study finds that state intervention can help local governments pursue policies that have an exclusionary nature, and so are not easily compromised among residents, such as multifamily housing zoning.

While the purpose of this study was to find evidence of multilevel governance structure in local multifamily housing zoning, future research should more directly investigate how state-level factors influence local governments' zoning decisions. More importantly, specific measures that show differences between conventional and smart growth management initiatives should be developed and tested in empirical 
models. Also, case studies can be conducted to analyze the dynamics of these two different growth management approaches' influence on the local multifamily housing supply.

\section{REFERENCES}

APA (American Planning Association). 2002. Planning for smart growth: 2002 state of the states. Washington, DC: Author. Retrieved August 4, 2012, from http://www .miami21.org/PDFs/Planning\%20for\%20Smart\%20Growth.pdf.

Anthony, J. 2004. Do state growth management regulations reduce sprawl? Urban Affairs Review, 39(3): 376-397.

Bollens, S. A. 1992. State growth management: Intergovernmental frameworks and policy objectives. Journal of American Planning Association, 58(4): 454-466.

Bryson, J. M., Crosby, B. C., \& Stone, M. M. 2006. The design and implementation of cross-sector collaboration: Propositions from the literature. Public Administration Review, 66 [Special issue: Collaborative public management]: 44-55.

Burge, G., \& Ihlanfeldt, K. 2006. The effects of impact fees on multifamily housing construction. Journal of Regional Science, 46(1): 5-23.

Carruthers, J. I. 2002. The impacts of state growth management programmes?: A comparative analysis. Urban Studies, 39(11): 1959-1982.

Chapman, J. I. 1988. Land use planning and the local budget. Public Administration Review, 48(4): 800-806.

Coase, R. H. 1937. The nature of the firm. Economica, 4: 386-405.

CPR (California Planning Roundtable). 2002. Myths and facts about affordable and high density housing. Retrieved August 4, 2012, from http://www.hcd.ca.gov/ hpd/mythsnfacts.pdf.

Emerson, K., Nabatchi, T., \& Balogh, S. 2011. An integrative framework for collaborative governance. Journal of Public Administration Research and Theory, 22(1): 1-29. doi: 10.1093/jopart/mur011.

Evans-Cowley, J. S., Forgey, F. A., \& Rutherford, R. C. 2005. The effect of development impact fees on land values. Growth and Change, 36(1): 100-112.

Feiock, R. C. 1994. The political economy of growth management. American Politics Quarterly, 22(2): 208-220.

Fischel, W. A., 1999. Zoning and land use regulation. Retrieved May 20, 2012, from http://encyclo.findlaw.com/2200book.pdf.

2001. An economic history of zoning and a cure for its exclusionary effects. Retrieved December 6, 2010, from http://www.dartmouth.edu/ wfischel/Papers/ 


$$
\text { 02-03.pdf. }
$$

Geyskens, I., Steenkamp, J. E. M, \& Kumar, N. 2006. Make, buy or ally: A transaction cost theory meta-analysis. Academy of Management Journal, 49(3): 519-543.

Gyourko, J., Saiz, A., \& Summers, A. 2007. A new measure of the local regulatory environment for housing markets: The Wharton residential land use regulatory index. Urban Studies, 45(3): 693-729.

Haughey, R. W. 2003. The case for multifamily housing. Washington, DC: Urban Land Institute.

Howell-Moroney, M. 2007. A mixed method look at state growth management policy. The American Review of Public Administration, 38(3): 339-361.

Kang, I., \& Feiock, R. C. 2006. Implementation of growth management policy in Florida cities: Zoning approval and regulatory policy enforcement. International Review of Public Administration, 11(1): 85-98.

Knapp, G., Meck, S., Moore, T. \& Parker, R. (2007) De we know regulatory barriers when we see them? An exploration using zoning and development indicators. Housing Policy Debate, 18(4): 711-749.

Lawhon, L. L. 2007. Local government use of development impact fees. In Municipal year book (pp. 11-14). Washington, DC: International City/County Management Association.

Lubell, M., Feiock, R., \& Ramirez, E. 2005. Political institutions and conversation by local government. Urban Affairs Review, 40(6): 706-729.

Mathur, S., Waddell, P., \& Blanco, H. 2004. The effect of impact fees on the price of new single-family housing. Urban Studies, 41(7): 1303-1312.

McCabe, B. C., \& Feiock, R. C. 2001. State rules and city money. Working paper, Lincoln Institute for Land Policy, Cambridge, MA.

McClure, K. 2008. Deconcentrating poverty with housing programs. Journal of the American Planning Association, 74(1): 90-99.

Miller, T. I. 1986. Must growth restrictions eliminate moderate-priced housing? Journal of American Planning Association, 52(3): 319-325.

Nelson, A. C., Pendall, R., Dawkins, C. J., \& Knaap, G. J. 2002. The link between growth management and housing affordability: The academic evidence. Washington DC: Brookings Institution Center on Urban and Metropolitan Policy.

Obrinsky, M., \& Stein, D. 2007. Overcoming opposition to multifamily rental housing. Washington, DC: National Multi Housing Council.

Ostrom, E. 1990. Governing the commons: The evolution of institutions for collective action. Cambridge: Cambridge University Press.

Ostrom, E. 2005. Understanding institutional diversity. Princeton: Princeton University Press. 
Park, S., Feiock, R., \& Kwon, S. 2012. Participants in local zoning decision and multifamily housing: Transaction costs and hierarchical governance. Working Paper. Presented at the annual meeting of 2011 Southern Political Science Association, New Orleans, Louisiana.

Park, J., Park, S., \& Lee, K. 2010. The adoption of state growth management regulation (SGMR): Regarding institutional analysis and development (IAD) framework and event history analysis. International Review of Public Administration, 15(2): 43-58.

Pendall, R. 1999. Do land-use controls cause sprawl? Environment and Planning B: Planning and Design, 26(4): 555-571.

Persson, T., \& Tabellini, G. 2000. Political economics. Cambridge, MA: MIT Press.

Peterson, P. E. 1981. City limits. Chicago: University of Chicago Press.

Tavares, A. F., Kassekert, A., Feiock, R. C., Lubell, M., \& Kang, I. 2008. Political institutions and land use decisions: A multi-level analysis of city and county choices. Paper presented at the annual meeting of the APSA 2008 Annual Meeting, Boston, Massachusetts.

Turner, B. S. 1990. Intergovernmental growth management: A partnership framework for state-local relations. Publius, 20(3): 79-95.

Wardrip, K., Williams, L., \& Hague, S. 2011. The role of affordable housing in creating jobs and stimulating local economic development: A review of the literature. Center for Housing Policy: Washington, DC. Retrieved August 4, 2012, from http://www.nhc.org/media/files/Housing-and-Economic-Development-Report -2011.pdf.

Weitz, J. 1999. From quiet revolution to smart growth: State growth management programs, 1960-1999. Journal of Planning Literature, 14(2): 266-337.

Williamson, O. E. 1975. Markets and hierarchies: Analysis and antitrust implications. New York: Free Press.

Yoo, D., \& Park, S. 2010. Understanding local politics and affordable housing. Korea Local Administration Review, 24(4): 423-448. 


\section{APPENDIX: WHARTON SCHOOL SURVEY QUESTION}

\section{[Independent variables]}

On a scale of 1 to 5 , please rate the importance of each of the following factors in regulating the rate of residential development regarding multifamily units in your community.

$(1=$ not at all important; $5=$ very important $)$

- Supply of land

- Cost of new infrastructure

- Density restrictions

- Impact fees

- City budget constraints

- City council opposition

- Citizen opposition

\section{[Dependent variable]}

How does the acreage of land zoned for the following land use compare to demand? $(1=$ far more than demanded; $5=$ far less than demanded $)$

- Multifamily housing 